\title{
Comparison of Sympathetic Activity by Use of Skin Conductance Monitor in Patients with and without Complex Regional Pain Syndrome
}

\author{
Kompleks Bölgesel Ağnı Sendromu Olan ve Olmayan Hastalarda Cilt İletkenlik Monitörü \\ Kullanılarak Sempatik Aktivitenin Karşılaştırılması
}

\section{Semih GÜNGÖR \\ (1D) 0000-0002-4484-9183}

Hospital for Special Surgery, Department of Anesthesiology, Critical Care and Pain Management, Weill Medical College of Cornell University, New York, USA

\begin{abstract}
Aim: Sympathetic system dysfunction has been described among the theories involved in the pathophysiology of complex regional pain syndrome. Objective measurement of the sympathetic activity of the affected extremity in patients with complex regional pain syndrome has not been compared to normal subjects in the literature. The skin conductance monitor is a non-invasive monitor that can objectively measure sympathetic skin activity of the extremity. In this study, we aimed to compare the differences in sympathetic activity of extremities in subjects with and without complex regional pain syndrome by using a skin conductance monitor.

Material and Methods: Sympathetic skin responses were evaluated in 63 subjects, including 25 measurements on the affected extremities in 13 patients with lower extremity complex regional pain syndrome type 1 and 50 measurements in 50 normal subjects in the control group. Among the skin conductance indices, the "peaks per second (0.02)" index was used as the main sympathetic skin response index. Descriptive criteria and the mean values of sympathetic skin response measurements were compared.

Results: When sympathetic skin responses were compared with a skin conductance monitor using the "peaks per second (0.02)" index, no statistically significant difference was found between the complex regional pain syndrome and control groups in terms of sympathetic activity in the extremities ( $\mathrm{p}=0.837$ ).

Conclusion: In this study, skin sympathetic nerve activity in the affected limb of patients with complex regional pain syndrome was similar to normal subjects. Further studies are required to assess the changes in sympathetic activity in complex regional pain syndrome.

Keywords: complex regional pain syndrome; reflex sympathetic dystrophy; skin conductance; sympathetic system; causalgia.
\end{abstract}

\section{ÖZ}

Amaç: Sempatik sinir sistem disfonksiyonu, kompleks bölgesel ağrı sendromu patofizyolojisinde yer alan teoriler arasında tanımlanmıştır. Kompleks bölgesel ağrı sendromu olan hastalarda etkilenen ekstremitenin sempatik aktivitesinin objektif ölçümü, literatürde normal denekler ile karşılaştııılmamıştır. Cilt iletkenlik monitörü, invazif olmayan ve ekstremitenin cilt sempatik aktivitesini objektif olarak ölçebilen bir monitördür. Bu çalışmada, kompleks bölgesel ağrı sendromu olan ve olmayan deneklerde ekstremitelerin sempatik aktivitesindeki farklılıkların bir cilt iletkenlik monitörü kullanılarak karşılaştırılması amaçlanmıştır.

Gereç ve Yöntemler: Sempatik cilt yanıtları, alt ekstremite kompleks bölgesel ağrı sendromu tip 1 olan 13 hastada etkilenen ekstremitelerden alınan 25 ölçüm ve kontrol grubundaki 50 normal denekten alınan 50 ölçüm olmak üzere 63 denekte değerlendirildi. Cilt iletkenlik endeksleri arasında "saniyede tepe sayısı $(0,02)$ " endeksi, ana sempatik cilt yanıt endeksi olarak kullanıldı. Tanımlayıcı kriterler ve sempatik cilt yanıt ölçümlerinin ortalama değerleri karşılaştırıldı.

Bulgular: Cilt iletkenlik monitörü ile "saniyede tepe sayısı $(0,02)$ " endeksi kullanılarak sempatik cilt yanıtları karşılaştırıldığında, kompleks bölgesel ağrı sendromu olan grup ile kompleks bölgesel ağrı sendromu tanısı olmayan kontrol grubu arasında ekstremitelerde sempatik aktivite açısından istatistiksel olarak anlamlı bir fark bulunmadı $(\mathrm{p}=0,837)$.

Sonuç: $\mathrm{Bu}$ çalışmada, kompleks bölgesel ağrı sendromu olan hastaların etkilenen ekstremitelerindeki cilt sempatik sinir aktivitesi, kompleks bölgesel ağrı sendromu tanısı olmayan normal denekler ile benzerdi. Kompleks bölgesel ağrı sendromunda sempatik aktivitedeki değişiklikleri değerlendirmek için daha ileri çalışmalara ihtiyaç vardır.

Anahtar kelimeler: kompleks bölgesel ağrı sendromu; refleks sempatik distrofi; cilt iletkenliği; sempatik sistem, kozalji.
Received / Gelis Tarihi : 31.01 .202 Accepted / Kabul Tarihi : 22.03.2021 Available Online /

Çevrimiçi Yayın Tarihi : 07.04.2021 


\section{INTRODUCTION}

The definitive pathophysiology of complex regional pain syndrome (CRPS) is unknown, but various concepts have been proposed (1). Dysfunction of the sympathetic system is among the proposed pathophysiological mechanisms (2) and is also included in the diagnostic criteria of CRPS (3). CRPS is classified into two subtypes (3): CRPS Type 1 and CRPS Type 2 (Table 1). CRPS patients may present as a warm-CRPS, usually in the early stages, or cold-CRPS, usually in the later stages (4). It is proposed that the sympathetic dysfunction might be responsible for clinical changes in the affected limb, such as under activity of the sympathetic nervous system in the warm-CRPS subtype and over activity of the sympathetic nervous system in the cold-CRPS subtype (2, Table 2). The current evaluations of proposed sympathetic changes in the affected limbs with CRPS are the indirect measurements of sympathetic activity. There is inadequate evidence in the scientific literature about the direct and objective measurement of the sympathetic activity of the affected limb in patients with CRPS. A skin conductance monitor (SCM) is a noninvasive monitor that can objectively measure the sympathetic activity in the limbs (5).

Skin conductance responses (SCR) can be measured in the limbs to reflect the variability of sympathetic nervous system activity. SCM is based on the concept that sympathetic nerves, when stimulated, act on muscarinic receptors in the skin to stimulate the sweat glands. When stimulated, the sweat glands secrete a mixture of sodium and other electrolytes, which will increase the electrical conductance and decrease the electrical resistance on the skin surface (6). This phenomenon can be monitored via SCM on palm and plantar skin using a computer program. The objective of this study was to compare the direct sympathetic activity by the use of sympathetic skin responses (SSR) in the limbs of subjects with and without a diagnosis of CRPS Type 1.

\section{MATERIAL AND METHODS}

After institutional review board (IRB) approval (Hospital for Special Surgery, 06.10.2020, 1039), subjects were recruited for this study, and written informed consent was obtained from each subject.

Table 1. CRPS, general subtypes (3)

\section{CRPS Type 1 (RSD)}

Absence of clinical signs of major peripheral nerve involvement CRPS Type 2 (Causalgia)

Presence of clinical signs of major peripheral nerve involvement CRPS: complex regional pain syndrome

Table 2. CRPS, warm vs cold subtypes (1)

\begin{tabular}{l} 
Warm-subtype \\
In the early and acute stages \\
Inflammatory characteristics are dominant \\
Associated with a warm, red, and edematous extremity \\
Cold-subtype \\
In the late and chronic stages \\
Autonomic features dominate \\
Associated with a cold, dusky, sweaty extremity \\
\hline CRPS: complex regional pain syndrome
\end{tabular}

The inclusion criteria include:

- Patients aged 18-99.

- Patients who are meeting the 2012 International Association for the Study of Pain (IASP) clinical criteria (i.e., the Budapest Criteria, Table 3) for CRPS (3) and with a clinically cold-CRPS subtype were recruited for the CRPS arm of this study.

- Normal subjects without the diagnosis of CRPS were recruited for the control arm.

The exclusion criteria include:

- patients having pacemakers, cardiac defibrillators, and spinal cord stimulators

- patients having dermatological conditions in the plantar aspect of the foot where SCM electrodes are going to be attached

- History of an allergic reaction to adhesive tape

- patients with the diagnosis of dysautonomia or sympathetic dysfunction (such as Raynaud disease or Buerger disease)

- patients with disorders of sweating (such as acquired idiopathic generalized anhidrosis)

- patients who use vasoactive drugs with the mechanism of action that directly influences vascular tone

The standard data obtained from both groups were as follows: Descriptive data including age, gender, body mass index (BMI). Skin conductance measurements for the "peaks per second (0.02)" index [peaks/sec (0.02) in microSiemens] were recorded for 5 minutes in each subject.

We hypothesized that in patients with cold-CRPS, SSRs would be higher in the affected extremity than normal subjects.

The SCM is a device that can measure changes in skin conductance in real-time to assess sympathetic activity in

Table 3. Budapest clinical diagnostic criteria for CRPS (7)

1. Continuing pain, which is disproportionate to any inciting event 2. Must report at least one symptom in three of the four following categories

- Sensory: reports of hyperesthesia and/or allodynia

- Vasomotor: reports of temperature asymmetry and/or skin color changes and/or skin color asymmetry

- Sudomotor/edema: reports of edema and/or sweating changes and/or sweating asymmetry

- Motor/trophic: reports of decreased range of motion and/or motor dysfunction (weakness, tremor, dystonia) and/or trophic changes (hair, nail, skin)

3. Must display at least one sign at time of evaluation in two or more of the following categories

- Sensory: evidence of hyperalgesia (to pinprick) and/or allodynia (to light touch and/or deep somatic pressure and/or joint movement)

- Vasomotor: evidence of temperature asymmetry and/or skin color changes and/or asymmetry

- Sudomotor/edema: evidence of edema and/or sweating changes and/or sweating asymmetry

- Motor/trophic: evidence of a decreased range of motion and/or motor dysfunction (weakness, tremor, dystonia) and/or trophic changes (hair, nail, skin)

4. There is no other diagnosis that better explains the signs and symptoms

CRPS: complex regional pain syndrome 
the limbs (Med-Storm Innovation version 2005, MedStorm, Oslo, Norway). Measurements can be obtained by use of three self-adhesive non-invasive electrodes denoted C (Current), R (Reference), and M (Measurement), and these electrodes can be attached to the palmar or plantar side of the skin (8-10). The definition of a skin conductance response is the sequence of the minimum followed by a maximum in conductance values in micro siemens $(\mu \mathrm{S})$. The SCR can be calculated in realtime, is typically analyzed in a sliding 15 seconds window, and updated each second (10). The measurements were recorded for 5 minutes in each subject.

The measurement unit uses the $\mathrm{C}$ and $\mathrm{R}$ electrodes in a feedback configuration to apply an exact and constant alternating voltage between the $\mathrm{R}$ and $\mathrm{M}$ electrodes. The return current from the M-electrode is recorded, as its value provides direct information on the skin conductance. The recorded alternating current signal is subjected to advanced filtering, removing noise and interference before the signal is sent on to the display computer (8-10). The system can measure conductance values in the range 1$200 \mu \mathrm{S}$, with a noise level below $0.002 \mu \mathrm{S}$. The measuring unit also has error detection that provides a warning for events caused by a loose electrode and external interference (8-10). The threshold for SCR recordings in this study was $0.02 \mu \mathrm{S}$.

Electrodes containing $\mathrm{AgCl}$ are used, and the measuring area under the M-electrode is critical because the SCR reflects the number of sweat glands below the electrode. The density of sweat glands on the palmar and plantar surface of hand/foot is consistent in normal subjects. The M-electrode is suited for the indices in the $\operatorname{SCM}(9,10)$.

The "peaks per second (0.02)" is a skin conductance monitor index that measures the frequency of sympathetic discharges at the skin and was reported to be the most reliable index for measurement of the skin sympathetic activity $(9,11)$.

Sympathetic skin responses were evaluated in 63 subjects, including 13 patients with lower extremity CRPS Type 1 (cold subtype) and a healthy control group including 50 individuals. SSRs were recorded on the affected extremities of patients with CRPS and normal extremities of the control group. A total of 25 SSR measurements were recorded on different days in 13 patients with CRPS. If more than one SSR measurement was obtained in a patient with CRPS, the mean value was used. In the control group, a total of $50 \mathrm{SSR}$ measurements were recorded in 50 healthy individuals. The "peaks per second (0.02)" index, which is reported to be the most reliable index for measuring sympathetic skin activity, was used as the main SSR index in this study. Descriptive criteria and the mean value of SSR measurements were compared in both groups.

A clinically meaningful difference in time to determine SSR between the CRPS group and the normal group was taken to be five minutes (300 seconds). Assuming a standard deviation of 180 seconds, 20 measurements would provide $80 \%$ power to detect a 300 -second difference in time to determine SSR between the CRPS and normal groups. Besides, skin conductance activity has shown a statistically significant increase during painful events in several studies $(9,10,12-19)$. In these studies, the number of patients to obtain statistically significant changes was between 20 and 75. Therefore, in this study, we estimated that 25 measurements in the CRPS group and 50 measurements in the normal (without CRPS) group would be appropriate to study how the SCR correlates with sympathetic activity between each group.

The study design made it impossible to blind the participants.

\section{Statistical Analysis}

Demographics were presented descriptively and compared between the CRPS and the control group. Continuous variables are summarized as means with standard deviations. Categorical variables are summarized as counts and percentages. For our primary outcome of interest, mean SSR recordings using the "peaks per second (0.02)" index was compared between the CRPS and the control group using two-sample t-test. We tested normality of the SSR before conduction t-test, Shapiro-Wilk test for normality, $\mathrm{p}=0.173$. The data was normal; therefore, we used a t-test for comparison. All statistical hypothesis tests were two-sided, with $\mathrm{p}$ values of less than 0.05 defined as statistically significant. All statistical analyses were performed using SAS version 9.4 (SAS Institute, Cary, NC). The data were compared statistically by a biostatistician who was not involved with the data collection process and was also blinded to this study's hypotheses and data groups.

\section{RESULTS}

Descriptive statistics are shown in Table 4. There was no statistically significant difference in regards to gender between the two groups $(\mathrm{p}=0.536)$. There were statistically significant differences in the age and BMI between the two groups ( $\mathrm{p}=0.016$ and $\mathrm{p}=0.001$, respectively).

When SSR were compared with a SCM using the "peaks per second (0.02)" index, no statistically significant difference was found between the CRPS and control groups in terms of sympathetic activity in the extremities $(\mathrm{p}=0.837$, Table 5).

\section{DISCUSSION}

In this study, we used SSR via SCM to reflect the variability of the sympathetic nervous system on the limbs in patients with CRPS. We compared it to similar data obtained from healthy subjects. The definitive pathophysiology of CRPS

Table 4. Comparison of demographic characteristics

\begin{tabular}{cccc}
\hline & Control $(\mathbf{n = 5 0})$ & CRPS $(\mathbf{n = 1 3})$ & $\mathbf{p}$ \\
\hline Gender, n (\%) & & & \\
Female & $26(52.0)$ & $5(38.5)$ & 0.536 \\
Male & $24(48.0)$ & $8(61.5)$ & \\
Age, mean (SD) & $64.11(8.71)$ & $53.46(13.34)$ & $\mathbf{0 . 0 1 6}$ \\
BMI, mean (SD) & $30.47(6.25)$ & $26.29(2.74)$ & $\mathbf{0 . 0 0 1}$
\end{tabular}

CRPS: complex regional pain syndrome, SD: standard deviation, BMI: body mass index

Table 5. Comparison of sympathetic skin responses

\begin{tabular}{lccc}
\hline & Control $(\mathbf{n = 5 0})$ & CRPS $(\mathbf{n}=\mathbf{2 5})$ & $\mathbf{p}$ \\
\hline Mean (SD) & $0.06(0.09)$ & $0.07(0.07)$ & \multirow{2}{*}{0.837} \\
[Min-Max] & {$[0-0.31]$} & {$[0-0.22]$} & \\
\hline CRPS: complex regional pain syndrome, SD: standard deviation &
\end{tabular}


is unknown, but various concepts have been proposed (1). Dysfunction of the sympathetic system is among the proposed pathophysiological mechanisms (2) and is also included in the diagnostic criteria of CRPS (3). CRPS is classified into two subtypes: CRPS Type 1 and Type 2. (3). CRPS patients may present as a warm-CRPS, usually in the early stages, or cold-CRPS, usually in the later stages (4). It is proposed that the sympathetic dysfunction might be responsible for clinical changes in the affected limb, such as under activity of the sympathetic nervous system in the warm-CRPS subtype and over activity of the sympathetic nervous system in the cold-CRPS subtype (2). The current evaluation of proposed sympathetic changes in the affected limbs with CRPS is an indirect measurement of sympathetic activity. There is inadequate evidence in the medical literature about the direct and objective measurement of the sympathetic activity of the affected limb in patients with CRPS. A skin conductance monitor (SCM) is a non-invasive monitor that can objectively measure the sympathetic activity in the limbs (5).

The evaluation of sympathetic activity in current practice is based on observation of clinical signs such as color changes due to increased blood flow, dilated cutaneous blood vessels, edema, and skin temperature monitoring. These clinical signs are often unpredictable, and various confounding factors like ambient temperature may influence the outcome. Hence, we propose using an objective evaluation method of sympathetic nerve activity via a SCM (MedStorm, Oslo, Norway). SCM is based on the concept that sympathetic nerves, when stimulated, act on muscarinic receptors in the skin to stimulate the sweat glands. When stimulated, the sweat glands secrete a mixture of sodium and other electrolytes, which will increase the electrical conductance and decrease the electric resistance on the skin surface (6). This phenomenon can be monitored via SCM on palm and plantar skin using a computer program. Various types of indices may be utilized that were incorporated into the software of SCM. Among these indices, an index, known as "peaks per second (0.02)", is a better indicator of the frequency of sympathetic discharges at the skin level (11). Therefore, we elected to use the "peaks per second (0.02)" index among SCM indices to compare the groups with and without a diagnosis of CRPS.

There was no difference in regards to gender between the two groups. There was a statistically significant difference in age and BMI, indicating the older age and higher BMI for the control group. However, it is unlikely that age and BMI interfere with skin conductance measurements (9).

This study did not demonstrate a significant difference between baseline sympathetic activity, measured by SCM by utilizing "peaks per second (0.02)" index, in the limbs of patients with and without CRPS. SCM has been shown to measure sympathetic activity in normal skin (9). Clinically, skin trophic changes are commonly observed in the advanced stages of CRPS, such as in the cold-CRPS subtype (1). Moreover, microscopic pathological changes have been documented in the skin biopsies taken from patients with CRPS $(20,21)$. It is also possible that these pathological changes may reduce the sensitivity of the SCM device and may not reflect the actual variations in the sympathetic activity of the limb that could have been otherwise detected in normal subjects. Further studies are needed to explore the sensitivity of other skin conductance indices and the potential contribution of other factors such as skin trophic changes to the skin sympathetic activity measurements via SCM.

The study design made it impossible to blind the participants and the data collectors. However, the biostatistician was blinded to study groups, the hypotheses of this study and was not involved in the data collection process. The other limitation of this study was that the number of subjects was different in each group. CRPS is a rare condition in the general population and often goes unrecognized by the medical community. The incidence of CRPS is approximately $5 \%$ in the orthopedic patient population after trauma or surgery (1). Among the patients with a diagnosis of CRPS, about $20 \%$ becomes chronic and progresses to a cold-CRPS subtype that clinically presents with the increased sympathetic activity such as the cold and clammy extremities (1). Therefore, the number of patients recruited for the cold-CRPS arm was limited to 13 patients during the study period, in whom a total of $25 \mathrm{SSR}$ measurements were obtained.

\section{CONCLUSION}

According to this study, skin sympathetic nerve activity in the affected limb of patients with CRPS was similar to normal subjects without the diagnosis of CRPS. Further studies are required to assess the changes in sympathetic activity in CRPS.

Ethics Committee Approval: The study was approved by the Ethics Committee of Hospital for Special Surgery, Weill Medical College of Cornell University (06.10.2020, 1039).

Conflict of Interest: None declared by the authors.

Financial Disclosure: None declared by the authors.

Acknowledgements: I would like to thank to Biostatistician Haoyan Zhong from Hospital for Special Surgery, Department of Research for statistical analysis and her contributions to the statistical section of this manuscript. I would like to thank to MedStorm, Oslo, Norway for providing Skin Conductance Monitor for research purposes.

Author Contributions: Idea/Concept: SG; Design: SG; Data Collection/Processing: SG; Analysis/Interpretation: SG; Literature Review: SG; Drafting/Writing: SG; Critical Review: SG.

\section{REFERENCES}

1. Bruehl S. Complex regional pain syndrome. BMJ. 2015;351:h2730.

2. Knudsen LF, Terkelsen AJ, Drummond PD, Birklein F. Complex regional pain syndrome: a focus on the autonomic nervous system. Clin Auton Res. 2019;29(4):457-67.

3. iasp-pain.org [Internet]. International Association for the Study of Pain. [Cited: 2021 Jan 31]. Available from: http://www.iasppain.org/files/Content/ContentFolders/Publications2/ ClassificationofChronicPain/Part_II-A.pdf. 
4. Bruehl S, Maihöfner C, Stanton-Hicks M, Perez RS, Vatine JJ, Brunner F, et al. Complex regional pain syndrome: evidence for warm and cold subtypes in a large prospective clinical sample. Pain. 2016;157(8):1674-81.

5. Gungor S, Rana B, Fields K, Bae JJ, Mount L, Buschiazzo V, et al. Changes in the skin conductance monitor as an end point for sympathetic nerve blocks. Pain Med. 2017;18(11):2187-97.

6. van Dooren M, de Vries JJ, Janssen JH. Emotional sweating across the body: Comparing 16 different skin conductance measurement locations. Physiol Behav. 2012;106(2):298-304.

7. Harden NR, Bruehl S, Perez RSGM, Birklein F, Marinus J, Maihofner C, et al. Validation of proposed diagnostic criteria (the "Budapest Criteria") for complex regional pain syndrome. Pain. 2010;150(2):268-74.

8. Gungor S, Storm H, Bae JJ, Rotundo V, Christos PJ. The effect of emotional stressors on postoperative skin conductance indices: a prospective cohort pilot study. Rev Bras Anestesiol. 2020;70(4):325-32.

9. Storm H. Changes in skin conductance as a tool to monitor nociceptive stimulation and pain. Curr Opin Anaesthesiol. 2008;21(6):796-804.

10. Storm H, Fremming A, Ødegaard S, Martinsen ØG, Moerkrid L. The development of a software program for analyzing spontaneous and externally elicited skin conductance changes in infants and adults. Clin Neurophysiol. 2000;111(10):1889-98.

11. Bini G, Hagbarth KE, Hynninen PT, Wallin BG. Thermoregulatory and rhythm-generating mechanisms governing the sudomotor and vasoconstrictor outflow in human cutaneous nerves. J Physiol. 1980;306(1):537-52.

12. Ledowski T, Bromilow J, Paech MJ, Storm H, Hacking $\mathrm{R}$, Schug SA. Monitoring of skin conductance to assess postoperative pain intensity. $\mathrm{Br} \mathrm{J}$ Anaesth. 2006;97(6):862-5.
13. Ledowski T, Bromilow J, Wu J, Paech MJ, Storm H, Schug SA. The assessment of postoperative pain by monitoring skin conductance: results of a prospective study. Anaesthesia. 2007;62(10):989-93.

14. Hansen JO, Storm H, Boglino-Hörlin A, Le Guen M, Gayat E, Fischler M. Skin conductance as a pain assessment tool during chest tube removal: an observational study. Eur J Pain. 2017;21(6):987-96.

15. Gjerstad AC, Wagner K, Henrichsen T, Storm H. Skin conductance versus the modified COMFORT sedation score as a measure of discomfort in artificially ventilated children. Pediatrics. 2008;122(4):e848-53.

16. Günther AC, Bottai M, Schandl AR, Storm H, Rossi P, Sackey PV. Palmar skin conductance variability and the relation to stimulation, pain and the motor activity assessment scale in intensive care unit patients. Crit Care. 2013;17(2):R51.

17. Hullett B, Chambers N, Preuss J, Zamudio I, Lange J, Pascoe E, et al. Monitoring electrical skin conductance: a tool for the assessment of postoperative pain in children? Anesthesiology. 2009;111(3):513-7.

18. Aslanidis T, Grosomanidis V, Karakoulas K, Chatzisotiriou A. Electrodermal activity monitoring during endotracheal suction in sedated adult intensive care unit patients. Folia Med (Plovdiv). 2018;60(1):92101.

19. Storm H, Myre K, Rostrup M, Stokland O, Lien MD, Raeder JC. Skin conductance correlates with perioperative stress. Acta Anaesthesiol Scand. 2002;46(7):887-95.

20. Albrecht PJ, Hines S, Eisenberg E, Pud D, Finlay DR, Connolly KM, et al. Pathologic alterations of cutaneous innervation and vasculature in affected limbs from patients with complex regional pain syndrome. Pain. 2006;120(3):244-66.

21. Oaklander AL, Rissmiller JG, Gelman LB, Zheng L, Chang Y, Gott R. Evidence of focal small-fiber axonal degeneration in complex regional pain syndrome-I (reflex sympathetic dystrophy). Pain. 2006;120(3):235-43. 